\title{
The impact of marketisation on undergraduate curriculum in an English university: A Bernsteinian analysis
}

\author{
Norman Brady ${ }^{a}$, Agnieszka Bates ${ }^{\mathrm{b}}$ \\ a University of Greenwich Business School \\ ${ }^{b}$ University of Roehampton, Froebel College
}

Received 23 June 2014; final version received 11 September 2014; accepted 12 September 2014

\begin{abstract}
The context for this paper is the marketisation of higher education in England since the 1990s which has established the core mission of the university as primarily economic. Successive government policies have framed this mission as the generation of 'useful' knowledge and the supply of skilled graduates required by companies to compete in the 'global economic race'. Higher education in the UK is now driven by a dynamic in which universities are required to compete for students in a quasimarket characterised by growing stratification and reduced state funding. This paper examines the impact of these changes in a case study of undergraduate curriculum in a university Business School. The data were collected through semi-structured interviews with academics who taught on undergraduate programmes together with a documentary analysis of texts such as module specifications, programme review documents and Business School strategy. Bernstein's pedagogic theory and in particular his concept of recontextualisation was utilised to interpret the findings. It was found that market imperatives relating to the maximisation of income generation dominate the discourse in the Business School. As a result, pedagogical relations have become recontextualised as a form of product management accompanied by a range of unintended consequences.
\end{abstract}

Keywords: curriculum, pedagogy, marketisation, discourse, Bernstein

The marketisation and massification of universities are the two grand narratives of higher education in the United Kindgom (UK) in the latter part of the 20th century, which continue to be played out in the 21st century (Naidoo, 2011). Writing nineteen years ago, Scott $(1995$, p. 5) observed that, during the 'turbulent half decade' between 1987 and 1992, participation in higher education almost doubled, from $14.6 \%$ to $27.8 \%$ and Britain 'acquired a mass system'. Some of the 'turbulence' was caused by the Further 
and Higher Education Act 1992, which created 74 'new' universities by granting university status to former polytechnics and colleges of higher education. Added to the already established universities, there were now 166 universities and higher education institutions (HEIs) in the UK (Scott, 1995). The expansion of universities post 1992 was driven by the New Labour government's vision for higher education articulated in the Dearing Report (1997) and developed through the policy of 'widening participation'. This policy encouraged 'non-traditional' students from families who had never before sent any other members to university to take up higher education study (ESRC, 2008, p.7).

However, what Scott, from the perspective of 1995, could not fully anticipate was the degree to which the mass system of higher education would be so comprehensively reconfigured by successive government policies into a quasi-market (Ainley, 2004). According to public policy reports (e.g. DBIS, 2010; Leitch, 2006), a 'university-knowledge economy nexus' has evolved in which the universities' core mission is to generate the knowledge and supply the 'highly skilled graduates' required by business to compete in the globalised 'knowledge economy'. The following statement by the former Secretary of State in the Department of Business Innovation and Skills (DBIS, 2010), Peter Mandelson, is typical of government discourse on the economic mission of universities:

Alongside its social and cultural role, higher education is, and will continue to be, central to this country's economic performance in the twenty first century. It is the key mechanism through which knowledge is generated, preserved and passed on. It equips people for the increasingly complex challenges of the modern workplace [...]. (DBIS, 2010, p. 7)

Neoliberal notions of a causal relationship between higher education and the growth of the 'knowledge economy' have now become deeply embedded in government discourse on higher education (Lauder et al., 2012). This discourse has been reified by the 'policy technologies' (Ball, 2003) of university league tables and tuition fees. The league tables signify the relative worth of universities by ranking them according to their 'performance'. For example, the recent Complete University Guide 2014 ranked UK universities' performance in a weighted average of nine indicators: expenditure per student on all academic services; completion rate of students; average entry standards score for students; expenditure per student on staff and 
student facilities; proportion of first and upper second degrees; measure of the employability of graduates; measure of the average quality of research; student satisfaction based on student evaluation of the teaching quality and student to staff ratio (Daily Telegraph, 2014). These performance indicators have acquired a new significance as a consequence of the Browne Report (2010) which, under the guise of the sustainability of the higher education system, recommended raising tuition fees. The fees were tripled by the current Coalition government who argued that raising tuition fees was necessary to ensure 'that teaching at our HEIs is sustainably financed [and] that the quality of that teaching is world class' (Browne, 2010, p. 2).

This paper contends that the discourse of the knowledge economy, together with the material influences of increased student tuition fees and university league tables have fundamentally altered the dynamics of university life, including teaching and learning. As Nixon (2008, p. 344) puts it:

The language of inputs and outputs, of clients and products, of delivery and measurement... is not just a different way of talking about the same thing. It radically alters what we are talking about. It constitutes a new way of thinking about teaching and learning. Ultimately, it affects how we teach and how we learn.

A university's reputation is now, to a large extent, contingent on its ranking which in turn is contingent on its 'performance' and which in turn determines its market attractiveness to the 'student consumer' (McArdle-Clinton, 2008). Bernstein's (2000) concept of recontextualisation is helpful in understanding how these dynamics shape discourse and action in educational contexts and it is to an exposition of his theory that we now turn.

\section{Bernstein's concept of recontextualisation}

Basil Bernstein (1924-2000) is considered in the UK as one of the founding fathers of the sociology of education which focuses on the specialised discourse of education, its construction and impact (Daniels, 2006). His main research project was concerned with analysing how the language of education is constructed (the invisible 'grammar') to encode legitimate knowledge. For Bernstein (2000) the 'grammar' or the pedagogic codes underpinning education discourse were infused with ideological properties which legitimated certain types of knowledge and which reflected power relations such as those contained in hegemonic forms of class relations (Sadovnik, 2001). 
Bernstein (2000) labelled this process for regulating education discourse the 'pedagogic device', which consisted of three hierarchical sets of rules: the distributive rules, the recontextualisation rules and the evaluative rules. This paper explores how Bernstein's theories and in particular his concept of recontextualisation might provide explanations for the specific relationship between higher education discourse and the curricular features found in the Business School. The operation of these hierarchical rules can be understood from a detailed analysis of pedagogic discourse within two main domains, the official recontextualising field (ORF) and the pedagogic recontextualising field (PRF). According to the theory of the 'pedagogic device', the Business School represents a 'pedagogic space' or a pedagogic recontextualising field (PRF) for knowledge generation and is conceptualised as a 'site of conflict' between competing discourses for control over the legitimacy of knowledge. The official recontextualising field (ORF) is represented by the state apparatus for regulating pedagogic discourse such as education funding agencies or quality assurance agencies, e.g. the Quality Assurance Agency for England (QAA), or departments of education responsible for designing or implementing education policies such as the Browne Report (2010). Bernstein (2000) refers to the official discourse on education as containing the distributive rules which set the 'limits', or 'ideological boundaries' of legitimate discourse. These rules define the goals and values of the education system over which the state has official governance. For example, by recommending the raising of tuition fees, the Browne Report (2010) reinforces the dynamic of marketisation and limits the discourse on development in higher education within the imperatives of financial sustainability and 'world class' quality. 'World class' quality, in turn, is regulated by the QAA university audit which applies performance indicators that are aligned with government policy. This makes the QAA a government agency rather than an independent quality assurance institution (Salter \& Tapper, 2000), further shaping the discourse on quality, performance measures and university league table rankings.

The recontextualising rules are derived from the distributive rules and regulate the enactment of pedagogic discourse in the pedagogic space (e.g. the Business School). Within the pedagogic space, discourse from the ORF and other PRFs (for example employer organisations and publishers such as Pearson Education Ltd) is continually decoded and recoded (recontextualised) into new pedagogic discourse by academics and university management. The discursive characteristics of the recontextualised curriculum and pedagogy 
can be further understood in terms of Bernstein's concepts of classification/ recognition and framing/realisation. Classification refers here to the location of the boundaries between disciplinary knowledge discourses and the nature of the boundaries themselves. Bernstein (2000) distinguished between strongly classified knowledge, such as that found in the traditional, 'pure', disciplines such as physics or history (which he termed 'singulars') and the new vocational subjects such as business studies (which he termed 'regions'), which were weakly classified. In Bernstein's theory, knowledge classification is a function of power $(+/-\mathrm{C})$ or the capacity of the discipline to insulate itself from outside influences or competing discourses. Classification contains within it recognition rules which provide both the academic and the student with the means to discriminate between 'knowledges' in terms of their relative legitimacy (Singh, 2002). Framing refers to the degree of regulation (+/- F) relating to the selection, sequencing, pacing and evaluation criteria in pedagogic practice. Framing contains realisation rules which guide academics in designing pedagogy and enable students to produce and reproduce legitimate texts, for example through the assessment regime. This paper contends that the Business School curriculum promotes narrow forms of technical/procedural knowledge that students are being asked to recognise as legitimate knowledge and to reproduce (realise) in assessment texts likely to lead to surface learning (Entwhistle, 1996). These rules are summarised in Table 1.

Table 1

Recontextualising pedagogic codes

\begin{tabular}{|c|c|c|}
\hline $\begin{array}{l}\text { Pedagogic } \\
\text { code }\end{array}$ & $\begin{array}{l}\text { Classification: relates to the } \\
\text { strength of the boundaries between } \\
\text { 'knowledges' (permeability) } \\
\text { Strongly classified +C } \\
\text { Weakly classified -C }\end{array}$ & $\begin{array}{l}\text { Framing: relates to the strength of } \\
\text { regulation in selection, sequencing, } \\
\text { pacing and evaluation of pedagogic } \\
\text { practice } \\
\text { Strongly framed }+F \\
\text { Weakly framed -F }\end{array}$ \\
\hline $\begin{array}{l}\text { Linked to } \\
\text { power or } \\
\text { control }\end{array}$ & $\begin{array}{l}\text { Power relations: create, legitimise } \\
\text { and reproduce boundaries. Operate } \\
\text { on relations between categories. }\end{array}$ & $\begin{array}{l}\text { Control: establishes legitimate } \\
\text { communications, provides regulation } \\
\text { over forms of communication } \\
\text { appropriate within categories. }\end{array}$ \\
\hline $\begin{array}{l}\text { Linked to } \\
\text { further codes } \\
\text { (the level of } \\
\text { the acquirer) }\end{array}$ & $\begin{array}{l}\text { Recognition rules: provide the } \\
\text { means for discriminating between } \\
\text { the relative legitimacy of different } \\
\text { 'knowledges' }\end{array}$ & $\begin{array}{l}\text { Realisation rules: enable appropriate } \\
\text { realisations to be produced/ } \\
\text { reproduced by learners }\end{array}$ \\
\hline
\end{tabular}

Note. Adapted from Bernstein (2000). 
The dynamic relations between the curriculum, pedagogy and evaluation have been summarised by Bernstein (1973, p. 85) as follows:

Curriculum defines what counts as valid knowledge, pedagogy defines what counts as valid transmission of knowledge, and evaluation defines what counts as a valid realization of the knowledge on the part of the taught.

As pointed out by Sadovnik (2001, p.4), Bernstein's project went beyond 'the description of the production and transmission of knowledge; he was concerned with its consequences for different [social] groups'. The core aim of his project was to develop a theory which

[...] analyzed the way in which changes in the division of labour create different meaning systems and codes, that provided analytic classifications of these systems, and that incorporated a conflict model of unequal power relations into its structural approach. (Sadovnik, 2001, p. 5)

Bernstein's theory, therefore, provides insight into the invisible grammar which underpins curriculum design and pedagogic practice in the Business School and its probable ideological origins. Here the findings reveal that the dominant discourse of marketisation and the knowledge economy has been recontextualised to define particular forms of 'useful knowledge'. Paradoxically, 'useful knowledge' has been coded as 'know-how' which valorises procedural knowledge at the expense of more powerful forms of knowledge which can take the learner beyond their immediate experience (Young, 2012). The negative consequences arising from the recontextualisation of curriculum design and pedagogic practice in the Business School provide the focus for the Key Findings section. Before that, the research methodology is outlined below.

\section{Research methodology}

A single case study research design was developed for the collection and analysis of empirical data (Yin, 2009). Defined as a research strategy for an empirical investigation of a particular phenomenon in its real life context (Yin, 2009), the case study was deemed suitably aligned with Bernsteinian conceptual framework. Specifically, the permeability of the boundaries between the case and its context (Yin, 2009) resonates with the concept of recontextualisation, both within the case (the Business School) (PRF) and in 
the interactions with its environment (ORF). The selection of the Business School and the undergraduate curriculum as the units of analysis arises from the valorisation of curricula linked to employability and other utilitarian aims in the dominant discourse emanating from government. The pedagogic robustness of curricula that purport to lead to positive educational and economic outcomes is, therefore, of current interest to educationalists.

The data were collected through semi-structured interviews $(n=24)$ with academics who taught on the two focal undergraduate programmes and a documentary review of relevant texts. The two undergraduate programmes: BA Business Studies (BS) and BA Entrepreneurship and Innovation (E\&I), were treated as 'embedded units of analysis' (Yin 2009). Interview questions concerned participants' perceptions of professional practice relating to programme validation, module design and pedagogy. Interview transcripts were coded using NVivo9.2 in order to identify themes and evaluate construct convergence/divergence.

\section{Key findings}

This research has found that as a consequence of recontextualisation, dominant approaches to curriculum design in the Business School are strongly aligned with the official discourse on the primacy of economic goals in higher education. Further, that this influence undermines pedagogic practice and pedagogical relations.

\section{The Business School}

The Business School is located in a 'new' University (post 1992) in the South of England which has a core student population of approximately 28,000, of which 22,000 are undergraduates. From its inception, and not surprisingly given its former polytechnic status, the university's mission and curriculum have been explicitly 'vocational'. The rapid expansion of the Business School from the late 1990s was driven by the New Labour's widening participation agenda. Typical of the 'new' universities, thousands of students were recruited locally, inspired by the government discourse of the knowledge economy and the promise of future careers in well-paid middle class occupations (DfES, 2002). These were frequently 'non-traditional students' (ESRC, 2008) who gained entrance to the Business School by mainly non-academic vocational pathways such as General National Vocational Qualifications 
(GNVQs) ${ }^{1}$. This historical context partly explains the ethos of undergraduate programmes that developed in the Business School in the late 1990s and into the 21st century.

Based on the analysis of the BS and E\&I handbooks, these programmes are characterised by a common core of curricular features and are explicitly vocational in their aim of preparing students for flexible, non-occupation specific career pathways. This flexibility is predicated on 'transferable' skills such as: communication; application of number; improving own learning; working with others; problem solving. The programme content is narrowly technicist and the pedagogy ostensibly based on 'student centred' learning. Above all, the programmes are assessment-driven and strongly framed $(+F)$ in terms of 'learning outcomes', often expressed as the attainment of skills (QAA, 2007). Of particular note in this regard was the diminution of theoretical knowledge in favour of 'know-how' or 'practical knowledge'. It does not seem implausible that to base expansion at the Business School on the recruitment of 'non-traditional' students, a curriculum needed to be designed which built on the particular educational capabilities of these students derived from their pre-university educational experiences and achievements.

As mentioned above, as a discipline of knowledge, business studies represents one of the 'new regions' (Bernstein, 2000). Unlike 'singulars' such as physics, which are strongly classified $(+C)$, the 'new regions' such as business studies are recontextualisations of 'singulars' such as economics, psychology and mathematics. They are weakly classified $(-C)$ and 'face outwards towards external fields of practice' and their 'contents are likely to be dependent on the requirements of these fields' (Bernstein, 2000, p. 55). This, in turn, makes the 'new regions' more susceptible to further recontextualisation, as curriculum designers are influenced by shifting discourses from 'outside'. This paper contends that, in Bernsteinian terms, the commoditisation of the curriculum in the Business School (PRF) is a direct consequence of its strong ideological alignment with the dominant discourse (ORF) of the knowledge economy and marketisation.

GNVQs were secondary level qualifications, related to business sub-disciplines rather than specific jobs and assessed mainly through coursework (rather than examination). GNVQs were discontinued in 2007. BTEC (Business and Technology Education Council) qualifications now offer similar post- 16 years vocational courses such as Business Studies; Travel and Tourism. The owners of BTEC, Pearson Education Ltd, currently promote BTEC as 'the world's most successful and best-loved applied learning brand' (Pearson, 2014). 


\section{The commoditisation of the curriculum}

Strategy documents provided the main policy vehicles for curriculum development in the Business School and often framed the curriculum as 'products' for the educational marketplace. The following example typifies the managerial discourse on the curriculum:

We will also broaden our portfolio of income generating activities to reduce our reliance on income from the traditional full-time home student market [...] We will also focus on operational efficiencies and so some programmes that have not demonstrated good recruitment potential will be discontinued. (Strategic Plan, 2010-13)

In alignmentwith government policy, management discourse recontextualised the university as a global business where opportunities for economic growth were given particular priority. For example:

After rapid expansion the School now aims to consolidate international operations around key strategic partners. This strategy has already started with the discontinuation of two small partners [...] New partners with strong financial backing and in locations with high growth potential will also be sought to expand the portfolio. (Strategic Plan, 2010-13)

The key point here is that the managerial discourse around curriculum and pedagogy was dominated by the values of income generation, efficiency and market competition. Consequently, undergraduate programmes were designed to maximise market demand for the least cost. This gave rise to the practice of the 'bundling' of undergraduate programmes. The Business School employed 140 academics but was nevertheless able to offer 97 discrete programmes clustered within programme 'suites' such as 'Business with..., e.g. 'Business with Marketing' or 'Business with Supply Chain Management'. This was achieved by constructing programmes within the programme suites to consist of a generic core of modules differentiated by a few modules in Years 2 and 3 and a discrete programme title. For example, if the BA Business Studies (BS) is compared with the BA Entrepreneurship and Innovation (E\&I), Year 1 modules are identical, Year 2 modules are also identical with the exception of two modules not available to BS students and one double credit core option not available to E\&I students. Year 3 is identical with the exception of two modules that appear as core on E\&I but only one of which can be taken on the BS. 
The approach to curriculum design based on market competitiveness and growth had important consequences for teaching. For example, modules within the programmes were arranged according to the principles of efficiency rather than pedagogy. Interview participants struggled to explain the relationship between the modules either within or between Years 1-3. One participant described the design of the 'Innovation' modules as 'bizarre' but explained that the lack of a relationship between modules was determined by 'access':

[...] the Entrepreneurship [programme] people should have done the second level module [Innovation 2]. So those people have come across innovation before, innovation in competitive environments. But most of my class, which is nearly two hundred strong, [...] are coming from BA Business Studies and the other general programmes. So you have to remember that for the people that I'm teaching, this is basically their first exposure. (Harrison)

In other words, accommodating students successfully on modules on different programmes required that modules had no prerequisites and were, therefore, discrete. Trevor identified a commoditised approach to curriculum design:

Well these [modules in the programme schema] were designed presumably at a time when student numbers were increasing, it was quite competitive, you tried to make attractive programmes that were good for the outside market. I mean, by and large this university's successful in doing that. (Trevor)

In rationalising curriculum design all but three interview participants cited key skills or employability as the key organising principles. There was little appreciation beyond three of the 24 participants that the principle of progression appeared to be ignored in the design of the programmes. There was no relationship between the modules cited by the participants except that they were 'relevant to business' and promoted key skills. In Bernsteinian terms the curriculum was weakly classified $(-\mathrm{C})$ and strongly framed $(+\mathrm{F})$ to produce incoherent but heavily regulated undergraduate programmes. This paradigm was reinforced by the erosion of pedagogical relations. 


\section{Erosion of pedagogical relations}

The first point of contact with the Business School by a potential undergraduate student is most likely to be its website. An analysis of textual data $^{2}$ available on the website confirms Trevor's evaluation of the curriculum as 'attractive... for the outside market'. The potential student is positioned as a 'customer' and 'offered' a 'teaching portfolio' of programmes as well as 'extras', such as an attractive location. These official website texts are couched in the language of 'success', 'cutting-edge practice', high 'student satisfaction' and a 'wide range of career options'. The teaching 'offered' by the Business School is referred to as 'helping', 'supporting', 'providing', 'giving' and 'equipping' students with the 'practical skills and knowledge employers need'. Student learning, in turn, is referred to as 'taking programmes', 'putting theory into practice', 'solving problems', 'doing' (e.g. 'doing business law'). This discourse objectifies and instrumentalises knowledge as something 'given' to the students (Molesworth et al., 2011). It overlooks the thinking, effort and dissonance or 'disjuncture' that are an inextricable part of the learning process (Jarvis, 2007). Instead, it conveys an overarching promise of 'equipping' students with skills and knowledge which will enable them to succeed in the job market. This, in turn, is symptomatic of an erosion of pedagogical relations, whereby university education becomes a transaction (Brady, 2012) based on student expectation to be given help during their studies and a job upon completion, in return for their investment ${ }^{3}$.

The intent underpinning the website discourse appears to be predominantly promotional, as exemplified by a video with 'sound bites' from a sample of Business School tutors and alumni. Their messages convey the 'benefits' of studying at the Business School through the use of hyperbole, for example 'absolutely fabulous' tutors (an alumna) and access to 'high flyer careers' (a tutor). In terms of the aims of specific degrees on offer, an introduction to the E\&I programme promotes 'learning to behave entrepreneurially' as one of three key reasons for studying the programme. This framing of learning in terms of superficial behavioural change, in conjunction with the discourse of success, seems to have affirmed student expectations, which often turn out to be a cause of dissonance. Based on the interview data and contrary

In order to ensure anonymity, the analysis of these data does not include longer quotations from the Business School website.

3 In line with universities of similar ranking, the Business School fees for home students total approximately $£ 25,500$ for a three-year undergraduate degree programme. 
to the website image of an 'energetic community', low student engagement has been a significant problem in the Business School. Issues around student engagement bemoaned by 19 of 24 participants included: 'shockingly' low attendance, refusal to read theoretically-oriented texts and to complete formative tasks. Low engagement was linked to the possibility that some tutors 'may not be interesting the students enough' because they do not contextualise theory by reference to up to date examples or 'stories' (Diana, Bruce). Trevor bemoaned the quality of case studies used for teaching as either 'out of date', irrelevant or 'uninteresting'. Most academics, however, appeared to link low engagement to students' personal attributes, by referring to students as 'lazy' or 'passive'. Rose saw the lack of student engagement as caused by wider cultural factors, particularly students' inappropriate expectations about learning acquired prior to coming to university:

The culture, everywhere. Just achieving a small thing and they are told: 'Excellent, you've done very well!' ... I question it. What does it mean that you've done very well?

In Bernsteinian terms, low student engagement is a symptom of pedagogy in which the process of learning is weakly framed $(-F)$, whilst learning outcomes (student satisfaction, future career) are strongly framed (+F). This triggers recognition rules which prioritise approaches to teaching as transmission of 'know-how' (often a pseudonym for information) and reconfigures student-teacher relations into those between the customer and service provider. Students as 'customers' pay to achieve success, for example a first class degree, through minimum effort on their part. Tutors, in turn, seek to 'engage' rather than challenge students and pacify those 'not satisfied' with the pedagogic realisation of the study experience 'offered' by the official website discourse. It is also possible to assume that students may learn to recognise and realise knowledge as 'disposable' after the successful completion of modules.

\section{Conclusion}

One of the main problems permeating the curriculum and pedagogy in the Business School is an overreliance on 'practical', 'transferrable' skills and a neglect of a coherent theoretical underpinning for undergraduate programmes of study. The fragmentation of the curriculum into largely discrete and disconnected modules appears to diminish the possibility of students 
engaging with a coherent 'system of meaning' (Wheelahan, 2010). Bernstein (2000, p. 157) refers to this problem as the closure of learner opportunities to engage with 'vertical discourse'. Vertical discourse offers conceptual understanding which transcends 'practical' experience and 'knowing-how'. Consequently, engaging with vertical discourse enables acquisition of the kind of knowledge which has genuine capacity for transferability across contexts or understanding beyond the student's personal experience. It is this kind of knowledge that may also be key to genuine 'employability' in the current context of fast-growing graduate unemployment (Allen \& Ainley, 2013).

However, as pointed out by Alvesson (2013, p. 90), the consequences of massification and marketisation of higher education are complex and a degree from a high-ranking university does not automatically guarantee access to 'attractive, well paid, and influential jobs'. By extrapolation, employment opportunities for 'non-traditional' graduates with degrees conferred by 'new' universities may be even more problematic. This is because the commoditised curriculum appears to close students' access to vertical discourse compounded by pedagogical relations which position them as 'passive' customers. Through his analysis of the pedagogic codes and their consequences for all involved in working and studying within the 'pedagogic space', Bernstein has thus made a contribution to our understanding of how, paradoxically, education may reproduce what it is tasked with eradicating - educational and social disadvantage. Thus whilst this case study has not sought to generalise to a statistical population, it does offer insight into some of the complexities of an interesting phenomenon which has arisen in the Business School. A Bernsteinian analysis of students' accounts of their experience of the commoditised curriculum in the marketised university in the wider European Higher Education Area would seem to offer a rich vein for future research.

\section{References}

Ainley, P. (2004). The new 'market-state' and education. Journal of Education Policy, 19(4), 497-514.

Allen, M., \& Ainley, P. (Eds.). (2013). Education beyond the coalition: Reclaiming the agenda. Retrieved from radicaledbks.com.

Alvesson, M. (2013). The triumph of emptiness: Consumption, higher education and work organization. Oxford: Oxford University Press.

Bernstein, B. (2000). Pedagogy, symbolic control and identity: Theory, research, critique. Oxford: Rowman \& Littlefield Publishers, INC. 
Bernstein, B. (1973). Class, codes and control, vol. 1. London: Routledge \& Kegan Paul.

Brady, N. (2012). From 'Moral Loss' to 'Moral Reconstruction' A critique of ethical perspectives in challenging the neoliberal hegemony in UK universities in the $21^{\text {st }}$ century. Oxford Review of Education, 38(3), 343-355.

Browne, J. (2010). Securing a sustainable future for higher education: An independent review of higher education funding \& student finance. Retrieved from http://webarchive. nationalarchives.gov.uk/+/hereview.independent.gov.uk/hereview/report/.

Daily Telegraph. (2014). The complete university guide. Retrieved from thecompleteuniversity guide.co.uk/league-tables/rankings.

Daniels, H. (2006). Activity, discourse and pedagogic change. In R. Moore, M. Arnot, J. Beck, \& H. Daniels (Eds.), Knowledge, power and educational reform: Applying the sociology of Basil Bernstein (pp. 163-178). London: Routledge

Dearing, R. (1997). Higher education in the learning society. London: HMSO. Retrieved from http://www.leeds.ac.uk/educol/ncihe/.

DfES (Department for Education and Skills). (2002). 14-19: Extending opportunities and raising standards: Summary guide. London: Stationery Office.

DBIS (Department for Business, Innovation and Skills). (2010). A strategy for sustainable growth. Retrieved from http://interactive.bis.gov.uk/comment/growth/files/2010/07/8782-BISSustainable-Growth_WEB.pdf.

Entwistle, N. (1996). Recent research on student learning. In J. Tait \& P. Knight (Eds.), The management of independent learning (pp. 97-112). London: Kogan Page.

ESRC (Economic and Social Research Council). (2008). Widening participation in higher education: A commentary by the Teaching and Learning Research Programme. Retrieved from http://www.tlrp.org/pub/documents/HEcomm.pdf.

Further and higher education act. (1992). Retrieved from http://www.legislation.gov.uk/ ukpga/1992/13.

Jarvis, P. (2007). Globalisation, lifelong learning and the learning society: Sociological perspectives. Oxon: Routledge.

Lauder, H., Young, M., Daniels, H., Balarin, M., \& Lowe, J. (2012). Educating for the knowledge economy? Critical perspectives. London: Routledge.

Leitch, S. L. (2006). Review of skills. Prosperity for all in the global economy - world class skills. Final report. Retrieved from http://www.ggpg.org.uk/governance-and-fe-system/leitchreport.html.

McArdle-Clinton, D. (2008). The consumer experience of higher education: The rise of capsule education. London: Continuum International Publishing Group.

Molesworth, M., Scullion, R., \& Nixon, E. (2011). The marketisation of higher education and the student as consumer. Oxon: Routledge.

Naidoo, R. (2011). Rethinking development: Higher education and the new imperialism. In R. King, S. Marginson, \& R. Naidoo (Eds.), Handbook on globalisation and higher education (pp. 40-58). Cheltenham: Edwin Elgar Publishing Ltd.

Nixon, J. (2008). Towards the virtuous university: The moral bases of academic practice. Oxon: Routledge.

Pearson Education Ltd. (2014). BTEC. Retrieved from http://www.edexcel.com/btec/Pages/ default.aspx. 
QAA (Quality Assurance Agency). (2007). Subject benchmark statements: General business and management. Retrieved from http://www.qaa.ac.uk/Publications/InformationAnd Guidance/Documents/GeneralBusinessManagement.pdf.

Sadovnik, A. R. (2001). Basil Bernstein (1924-2000). Prospects: The quarterly review of comparative education, 31(4), 687-703.

Salter, B., \& Tapper, T. (2000). The politics of governance in higher education: The case of quality assurance. Political Studies, 48(1), 66-87.

Scott, P. (1995). The globalization of higher education. Buckingham: SRHE and Open University Press.

Singh, P. (2002). Pedagogising knowledge: Bernstein's theory of the pedagogic device. British Journal of Sociology of Education, 23(4), 571-582.

Wheelahan, L. (2010). Why knowledge matters in curriculum: A social realist argument. London: Routledge.

Yin, R. K. (2009). Case study research: Design and methods. London: Sage Publications.

Young, M. (2012). The curriculum - 'An entitlement to powerful knowledge': A response to John White. New visions for education. Retrieved from http://www.newvisionsforeducation. org.uk/2012/05/03/the-curriculum-\%E2\%80\%98an-entitlement-to-powerfulknowledge\%E2\%80\%99-a-response-to-john-white/

\section{Authors}

Dr Norman Brady, University of Greenwich Business School, Queen Anne Court 306, Greenwich Maritime Campus, Park Row, London, SE10 9LS, e-mail: nbrady02@mail.bbk.ac.uk.

Dr Agnieszka Bates, University of Roehampton, Froebel College, Roehampton Lane, London SW15 5PJ, e-mail: agnieszka.bates@roehampton.ac.uk.

\section{Vliv marketizace na kurikulum bakalářského studia na anglické univerzitě: Bernsteinovská analýza}

Abstrakt: Kontext tohoto příspěvku tvoří marketizace terciárního vzdělávání v Anglii, která probíhá od devadesátých let dvacátého století a podle které je hlavní funkcí univerzity funkce ekonomická. Několik po sobě jdoucích vládních strategií zaštitovalo tento přístup voláním po vytváření „užitečných“ poznatků a po zásobě šikovných absolventů, které potřebují firmy, aby mohly uspět v „globálních ekonomických závodech“. Terciární vzdělávání ve Spojeném království je nyní poháněno takovou dynamikou, ve které jsou univerzity nuceny soutěžit o studenty na kvazi-trhu, pro který je charakteristická rostoucí stratifikace a snížené financování státem. Tento příspěvek zkoumá dopad těchto změn v rámci případové studie kurikula bakalářského studia na ekonomické fakultě jedné z univerzit (a university Business School). Sběr dat probíhal pomocí polostrukturovaných rozhovorů s vyučujícími v bakalářských 
programech. Dále byla uskutečněna analýza dokumentů (napřs. specifikace studijních modulů, oficiální hodnocení a revize studijních programů, strategie fakulty apod.). K interpretaci výsledků byla využita bernsteinovská pedagogická teorie, především pak koncept rekontextualizace. Analýzy naznačují, že diskurzu na Business School dominují požadavky trhu vztahující se k maximalizaci generovaného př́jmu. Výsledkem je rekontextualizace pedagogických vztahů jako formy řízení produktu, kterou doprovází řada nezamýšlených důsledků.

Klíčová slova: kurikulum, pedagogika, marketizace, diskurz, Bernstein 